\title{
Historical perspectives of The American Association for Thoracic Surgery: Joseph S. Coselli, MD
}

\author{
Scott A. Hittinger, MD, Tom P. Theruvath, MD, PhD, and John S. Ikonomidis, MD, PhD
}

\author{
From the Division of Cardiothoracic Surgery, Medical University of South Carolina, Charleston, SC. \\ Disclosures: Authors have nothing to disclose with regard to commercial support. \\ Received for publication Sept 7, 2016; accepted for publication Sept 16, 2016; available ahead of print Oct 14, \\ 2016. \\ Address for reprints: John S. Ikonomidis, MD, PhD, Division of Cardiothoracic Surgery, Medical University of \\ South Carolina, 114 Doughty St, Suite BM 282, Charleston, SC 29425 (E-mail: ikonomij@musc.edu). \\ J Thorac Cardiovasc Surg 2017;153:2-5 \\ $0022-5223 / \$ 36.00$ \\ Copyright (c) 2016 by The American Association for Thoracic Surgery \\ http://dx.doi.org/10.1016/j.jtcvs.2016.09.034
}

Joseph Stapleton Coselli was born on October 28, 1952, in Houston, Texas, as 1 of 4 sons to Doris L. Coselli and John A. Coselli, Sr. Coselli was raised in a typical postwar family, less than a decade removed from World War II. His mother was a school teacher responsible for 4 boys2 future lawyers and 2 future doctors. His dedicated father was the youngest son of an Italian immigrant emerging from humble beginnings. His father became an accomplished attorney managing a title company. The family achieved success in the legal profession, ensuring financial stability and a good lifestyle, but above all education was considered paramount—beyond just remuneration. Joseph Coselli, a year younger than his classmates, enrolled at George W. Strake Jesuit High School, where he excelled academically. During the summers, he worked for Commercial Title Company, his father's title company, driving a pickup truck without an air conditioner or functioning gas gauge to make deliveries between banks, savings and loans, and title companies. With perseverance and aplomb, he graduated to making title changes, checking property leans, and performing background title searches. After watching his brothers and cousins progress through law school, Coselli seemed determined for a career in law. With these intentions, Joseph Coselli set out for the University of Notre Dame in 1970 (Figure 1). While there, he excelled in math, physics, science, and chemistry, performing better than his peers. During his freshman year, Coselli watched as the title company was sold to a Chicago-based firm. Coselli returned back to Houston without a job for the summer.

With little familial exposure to surgery, Joseph Coselli sought a summer job from his cousin, a nurse working in the intensive care unit for Dr Denton Cooley in Houston. Amidst the Texas Heart Institute explosion of cardiac surgery, Joseph Coselli, with his hair "a little bit too long" (J.S. Coselli, personal communication, April 26, 2016), met with Denton Cooley and was assigned to the pump team of Charlie Reed, the first president of the American Board of Cardiovascular Perfusion. During his

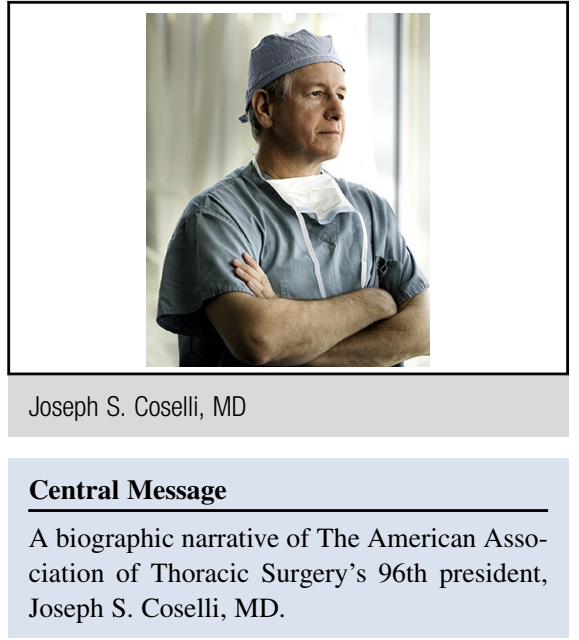

first day, Joseph Coselli looked over the ether screen and watched as Denton Cooley repaired a syphilitic arch aneurysm. The environment was unbelievable, and 25 to 30 pump cases a day was routine. For Coselli, at that moment just on the other side of the ether screen, "it just clicked . . . [I decided] to become a cardiac surgeon and [I] never wavered; never looked back; never regretted a minute of it" (J.S. Coselli, personal communication, April 26 , 2016.) As a young college student, Coselli not only helped the pump team but he also scrubbed in, held retractors, and assisted with cannulation. The experience of that summer and the ones that would follow would factor prominently throughout Joseph Coselli's life.

\section{EDUCATION AND SURGICAL TRAINING}

Joseph Coselli graduated from George W. Strake Jesuit College Preparatory and traveled a thousand miles north to the University of Notre Dame, where he enrolled in 1970. The excellent marks he obtained in his undergraduate career prepared him for the strict, regimented demands of medicine and surgery. While working for Dr Cooley, Coselli had become driven to become a cardiac surgeon and formulated a plan. Before finishing his undergraduate work, he realized that most of Cooley's partners had gone through Dr Michael DeBakey's surgery residency program at Baylor University College of Medicine. He therefore decided that he needed to train there as well. After completion of his undergraduate work with a bachelor's degree in biology, Coselli enrolled at the University of Texas Medical Branch in Galveston in 1974. Manifesting self-discipline, he completed the 4-year program in 3. 


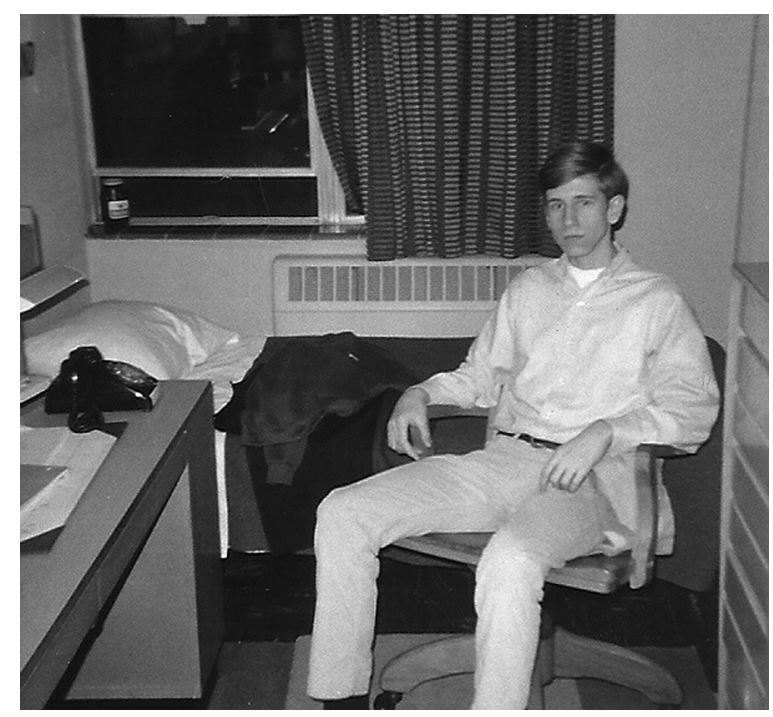

FIGURE 1. Dr Coselli at Notre Dame University (1970).

Again, he performed at the top of his academic class. Everything aligned, and Coselli landed a coveted residency position in Dr DeBakey's program, rotating through the service as a junior resident and later as a maturing senior. Dr DeBakey's service offered many rotations in cardiac surgery and prepared Coselli well. Dr DeBakey's service was "a welloiled machine," with no room for inefficiency or waste because "inattention to detail [was] the hallmark of mediocrity." At times, DeBakey had more than 100 personal patients in house, with more than 20 to 25 patients in the intensive care unit at one time. Managing the service necessitated efficiency, knowledge, and excellence. This experience prepared Coselli well for upper level rotations. Coselli was a dependable, astute, meticulous surgical trainee. As an upper level resident, he worked on the service of Dr E. Stanley Crawford at Methodist Hospital, but was struck down by hepatitis and rendered incapable of finishing Crawford's rotation. Coselli was effectively disabled for 6 weeks while he recovered. Shortly after his return, one of his mentors, Dr Arthur Beall, met him in the hallway and told him that Dr DeBakey wanted Coselli to stay on for thoracic surgery fellowship and wanted him to sign the contract immediately. Two years later, as Coselli was completing his congenital heart surgery rotation in Saudi Arabia, he received the call from E. Stanley Crawford, "When you finish, if you elect to, come on board" (J.S. Coselli, personal communication, April 26, 2016). With his hand on Coselli's shoulder, Crawford altered the trajectory of Joseph Coselli's surgical career. Their arrangement was a handshake deal on $100 \%$ commitment to excellence. Success followed a tough year of nights, weekends, and utter dedication. Coselli had clearly impressed Dr Crawford, known for a genius mind residing behind Southern drawl. Dr Crawford later approached him and said, "Goodbyes come and go. How would you like to really stay here?" (J.S. Coselli, personal communication, April 26, 2016) Coselli flourished as a junior associate under the leadership of Dr Crawford, his closest mentor and fundamental ally. During that year, Dr Crawford ushered him through the world of academics. Coselli answered the call of publishing, and Dr Crawford sponsored him to join societies and introduced him to other colleagues.

\section{SURGICAL CAREER}

After the completion of his fellowship in 1984, Joseph Coselli became a junior associate of Dr Crawford. Crawford typically had 2 junior associates at a time, running a wide regional and national referral base with dedication to general, vascular, and cardiac surgery. During his first year, Coselli matured academically and clinically. $\mathrm{He}$ published extensively and presented at national conferences. At the end of a grueling and thrilling year, Dr Coselli decided to stay on with Dr Crawford. He rose quickly through the first 7 years of his career. He developed into a reliable partner and a supreme technical surgeon.

On January 31, 1991, Dr Crawford suffered a debilitating stroke, and Coselli abruptly transitioned into the senior role. With Dr DeBakey's approval and under his watchful gaze, Drs Coselli and Hazim Safi split Crawford's service. Overnight, the expanding volume and responsibilities were thrust upon Coselli. He astutely narrowed his focus to cardiovascular surgery. The transition was seamless, and eventually Safi changed institutions, leaving Coselli to run Crawford's service on his own. With the accumulation of experience and continued tireless drive and hard work, Coselli emerged as a confident leader and became professor and chief of the division of cardiothoracic surgery and the director of the thoracic surgery residency program at Baylor College of Medicine.

\section{CURRICULUM VITAE HIGHLIGHTS}

In more than 30 years of professional service, Joseph Coselli has performed more than 7000 aortic operations, with nearly half being thoracoabdominal aortic operations. He exploded onto the academic surgical scene in the early 1980s, and during the interim has published more than 350 academic articles and more than 100 book chapters, has lectured more than 500 times nationally and internationally, and has written and coedited Aortic Arch Surgery: Principles, Strategies and Outcomes, published by Wiley-Blackwell. Joseph Coselli has served in leadership roles throughout his professional career, from local organizations to national societies. He has been president of the Texas Surgical Society (2008), the Michael E. DeBakey International Surgical Society (2010), the Southern Thoracic Surgical Association (2011), the Denton A. Cooley Cardiovascular Surgical 


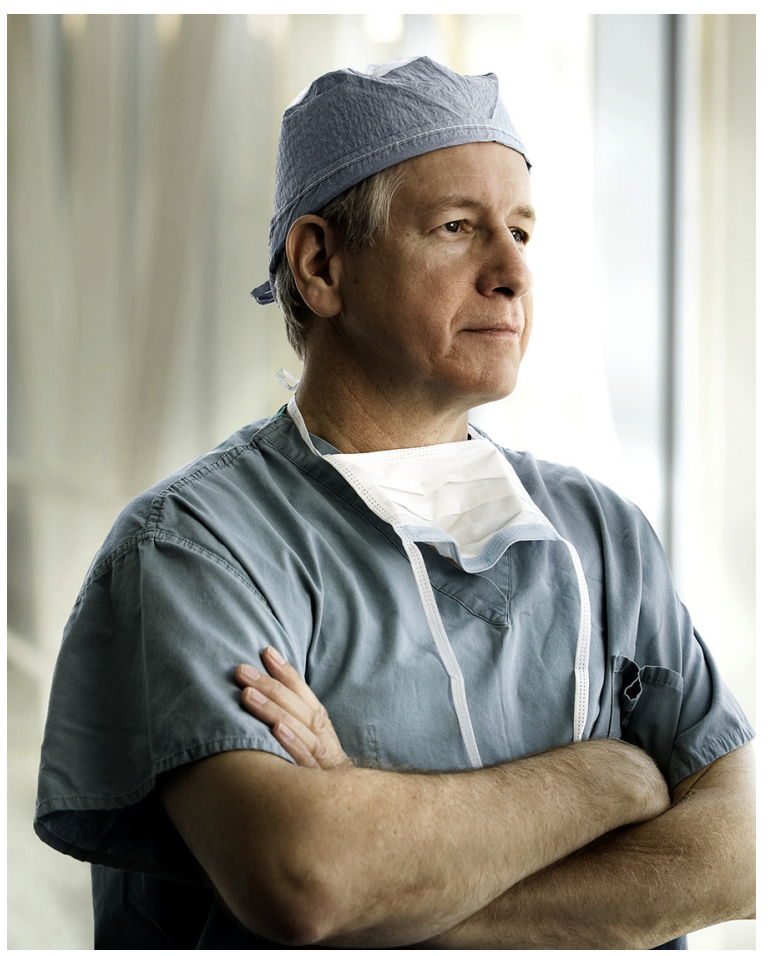

FIGURE 2. Joseph S. Coselli, MD, 96th president of The American Association of Thoracic Surgery.

Society (2012), and The American Association of Thoracic Surgery (2016). Dr Coselli has received multiple awards, including the Antoine Marfan award, the Emil T. Hoffman award from the Department of Chemistry and Biochemistry of Notre Dame, and the Michael E. DeBakey Excellence in Research Award in 2001.

\section{ACCOMPLISHMENTS AND CONTRIBUTIONS TO THE FIELD OF CARDIOTHORACIC SURGERY}

Dr Coselli's greatest contribution to the field is likely the comprehensive delineation of the surgical treatment of diseases of the thoracoabdominal aorta. Coselli and colleagues $^{2}$ published the article "Outcomes of 3309 Thoracoabdominal Aortic Aneurysm Repairs" in the May 2016 issue of The Journal of Thoracic and Cardiovascular Surgery. ${ }^{2}$ This seminal article embodied the completeness of more than 28 years of astronomical labor, defining the predictors of early death and other adverse postoperative outcomes in patients with thoracoabdominal aortic aneurysm repair. Dr Coselli's pioneering work with the use of left heart bypass, ${ }^{3}$ cerebrospinal fluid drainage, ${ }^{4,5}$ and abdominal visceral perfusion ${ }^{6}$ has shifted the paradigm of care in thoracoabdominal aortic surgery. Joseph Coselli firmly stands tall among the great cardiac surgeons, emerging from the shadows of Texas greats: DeBakey, Cooley, and Crawford (Figure 2).

\section{AATS PRESIDENTIAL ADDRESS}

Dr Coselli's presidential address was presented at the 96th annual meeting of The American Association for Thoracic Surgery in Baltimore, Maryland. Dr Coselli expressed gratitude to his own mentors, Drs Michael DeBakey, Denton Cooley, and E. Stanley Crawford. Dr Coselli made a pointed argument focusing on the benefits of competition and how it has facilitated quantum leaps in achievement, but he also identified cases in which medical competition has hindered progress. He identified the discovery of DNA, the polio vaccine, and the discovery of the human immunodeficiency virus as instances in which competition restricted progress and knowledge advancement. He noted the personal competition between Drs Cooley and DeBakey and stated

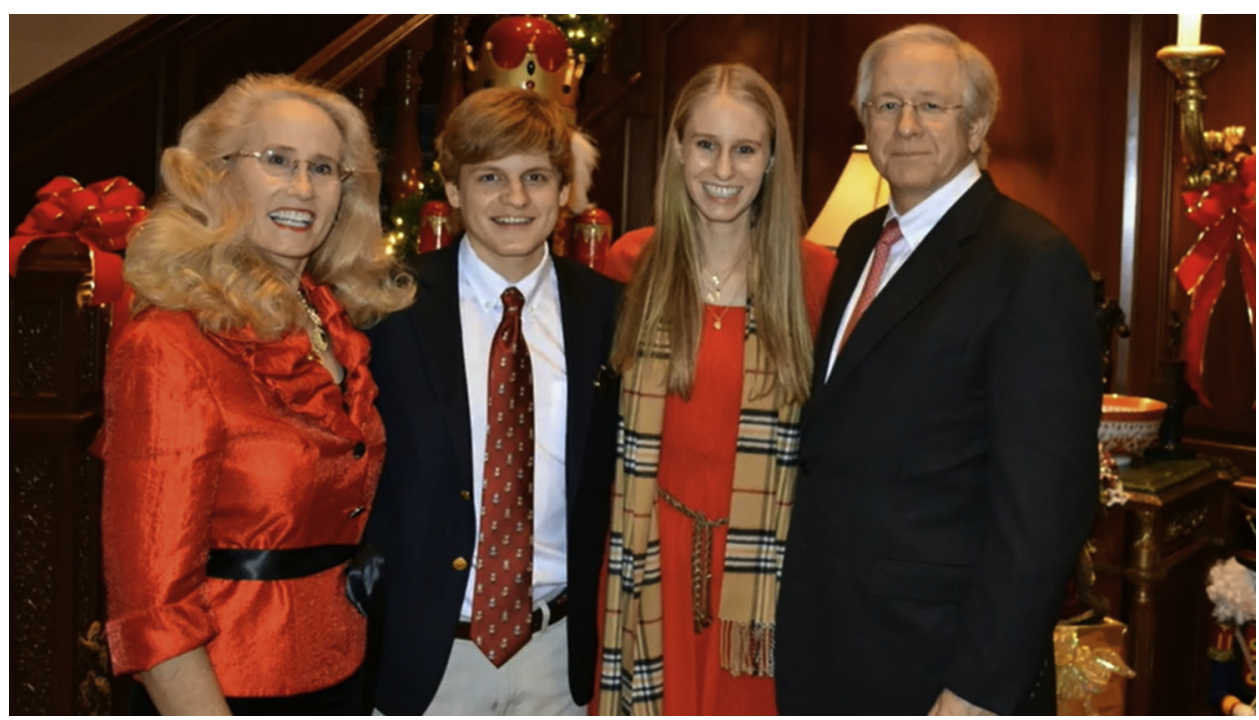

FIGURE 3. Dr Coselli with his family. 
that "they competed with the ferocity of gladiators." 40-year feud yielded enormous productivity "for both of these surgeons to [the] benefit [of] the cardiovascular community." 7 Dr Coselli noted the surgeon's competition versus disease in the advancement of procedures to benefit cure. He strongly suggested that we, as an association, embrace healthy competition. Finally, Dr Coselli drew attention to the role that patients have played in furthering the medical community's knowledge of cardiothoracic surgery.

\section{PERSONAL LIFE}

Dr Coselli's highly regarded wife, Kelly, is a member of several volunteer organizations, dividing her time among Houston philanthropy, their children, and Dr Coselli (Figure 3). The Cosellis have 2 children. The elder, Catherine, is an equestrian of the highest caliber and became an expert in the hunter jumper discipline. Her love of horses has been a lifelong passion. The younger, Joseph, is a superb marksman and also a superb student, particularly in the science and math disciplines. Dr Coselli enjoys hunting and playing golf.

\section{References}

1. Frazier OH. Michael E. DeBakey, 1908 to 2008. J Thorac Cardiovasc Surg. 2008; 136:809-11.

2. Coselli JS, LeMaire SA, Preventza O, de la Cruz KI, Cooley DA, Price MD, et al Outcomes of 3309 thoracoabdominal aortic aneurysm repairs. J Thorac Cardiovasc Surg. 2016;151:1323-38.

3. Coselli JS, LeMaire SA. Left heart bypass reduces paraplegia rates after thoracoabdominal aortic aneurysm repair. Ann Thorac Surg. 1999;67:1931-4.

4. Köksoy C, LeMaire SA, Curling PE, Raskin SA, Schmittling ZC, Conklin LD, et al. Renal perfusion during thoracoabdominal aortic operations: cold crystalloid is superior to normothermic blood. Ann Thorac Surg. 2002; 73:730-8.

5. Crawford ES, Svensson LG, Hess KR, Shenaq SS, Coselli JS, Safi HJ, et al. A prospective randomized study of cerebrospinal fluid drainage to prevent paraplegia after high-risk surgery on the thoracoabdominal aorta. J Vasc Surg. 1991;13:36-45; discussion 45-6.

6. Coselli JS, LeMaire SA, Köksoy C, Schmittling ZC, Curling PE Cerebrospinal fluid drainage reduces paraplegia after thoracoabdominal aortic aneurysm repair: results of a randomized clinical trial. J Vasc Surg. 2002;35:631-9.

7. Coselli JS. Competition: perspiration to inspiration "aut inveniam viam aut faciam." J Thorac Cardiovasc Surg. 2016;152:1215-22.

Access to The Journal of Thoracic and Cardiovascular Surgery Online is reserved for print subscribers!

Full-text access to The Journal of Thoracic and Cardiovascular Surgery Online is available for all print subscribers. To activate your individual online subscription, please visit The Journal of Thoracic and Cardiovascular Surgery Online, point your browser to http://www.mosby.com/itcvs, follow the prompts to activate your online access, and follow the instructions. To activate your account, you will need your subscriber account number, which you can find on your mailing label (note: the number of digits in your subscriber account number varies from 6 to 10). See the example below in which the subscriber account number has been circled:

\section{Sample mailing label}

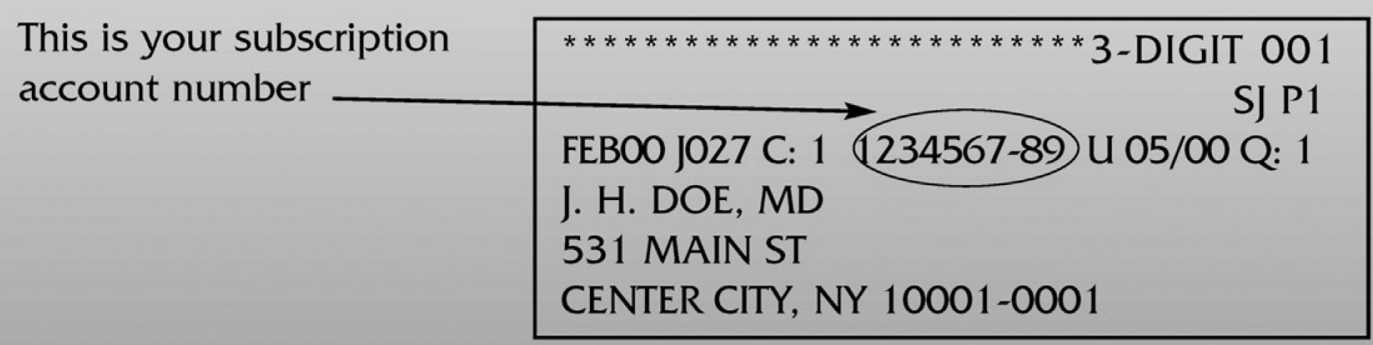

Personal subscriptions to The Journal of Thoracic and Cardiovascular Surgery Online are for individual use only and may not be transferred. Use of The Journal of Thoracic and Cardiovascular Surgery Online is subject to agreement to the terms and conditions as indicated online. 